\title{
Diversity of Cordyceps Fungi in Nepal
}

\author{
Bhushan Shrestha \\ Green Energy Mission/Nepal, Anam Nagar, Kathmandu \\ e-mail: bhushanshrestha2004@yahoo.com
}

\begin{abstract}
Fungi are a part of the biodiversity that play a significant role in daily livelihood of the local communities. Yarsagumba (Ophiocordyceps sinensis) is one of the highly valued medicinal fungi that grow in the Tibetan Plateau of China and alpine grasslands of Nepal, Bhutan and India. Genus Cordyceps was recently revised and divided into four genera: Cordyceps, Elaphocordyceps, Metacordyceps and Ophiocordyceps, based on molecular phylogeny and morphology. The recent revision has consequently changed the scientific name of Yarsa gumba from Cordyceps sinensis (Berk.) Sacc. to Ophiocordyceps sinensis (Berk.) Sung et al. In Nepal, scientific study of Cordyceps species started about 60 years ago. During last 30 years, different Cordyceps species have been reported from Nepal. In this paper, Cordyceps species reported from Nepal have been discussed along with their synomyms, morphological characters, hosts and distributions in the global context.
\end{abstract}

Key words: Cordyceps, Elaphocordyceps, Metacordyceps, Ophiocordyceps, Yarsagumba

\section{Introduction}

More than 500 Cordyceps species have been reported in the world (http://www.indexfungorum.org/Names/ Names.asp). Cordyceps species are regarded as medicinal fungi in the oriental societies of Asia including Nepal. Recently, Sung et al. (2007) revised the megagenus Cordyceps and separated it into 4 genera, namely, Cordyceps (fam. Cordycipitaceae), Elaphocordyceps and Ophiocordyceps (fam. Ophiocordycipitaceae) and Metacordyceps (fam. Clavicipitaceae) in the Order Hypocreales of Phylum Ascomycota of the Kingdom Fungi, based on molecular phylogeny. Ophiocordyceps sinensis (Berk.) Sung et al. (syn. Cordyceps sinensis (Berk.) Sacc.), popularly known as Yarsagumba in Nepal, is one of the most regarded medicinal fungi. Atreya Samhita has mentioned it as Bhu-Sanjibani that cures severe and incurable kidney and syphilis diseases (Shrestha 2010b,c, 2011, Shrestha et al. 2010). Chinese literatures have also mentioned different medicinal values of $O$. sinensis since last two thousand years and have officially included it in Chinese pharmacopeia (Jones 1997, Zhu et al. 1998, Halpern 1999, Mizuno 1999, Li \& Tsim 2004, Holliday et al. 2005, Li et al. 2006, Winkler 2008). It is popularly known as an aphrodisiac herb in folk herbal medicine in Nepal (Sacherer 1979, Bhattarai 1993). O. sinensis is naturally distributed in the northern alpine grasslands of Nepal, Bhutan and India and in Tibetan Plateau of China, ranging from 3000 to $5000 \mathrm{~m}$ above sea level (Balfour-Browne 1955, DMP 1970, Sacherer 1979, Kobayasi 1980, 1981, Otani 1982, Shrestha 1985, Adhikari \& Durrieu 1996, DPR 1997, Chen et al. 1999, 2004, Mizuno 1999, Adhikari 2000, 2008, Kinjo \& Zang 2001, Liu et al. 2001, Winkler 2004,2010, Chhetri 2005, Holliday et al. 2005, Shrestha \& Sung 2005, Canney 2006, Devkota 2006, 2008a,b, 2009, Li et al. 2006, Halpern 2007, Amatya 2008, Chhetri \& Lodhiyal 2008, Shrestha et al. 2010, Singh et al. 2010, Weckerle et al. 2010). Besides O. sinensis, different Cordyceps species have been reported in Nepal during last 30 years. The reported Cordyceps species are described below. 
I) FAMILY Clavicipitaceae (Lindau) Earle ex Rogerson, emend. Sung et al., Stud. Mycol. 57:27, 2007.

1) Metacordyceps liangshanensis (Zang et al.) Sung et al., Stud. Mycol. 57:35, 2007. (Fig. 1)

三 C. liangshanensis Zang et al., Acta Bot. Yunnanica 4:174, 1982.

Morphological characters: Stromata solitary or branched, light to dark brown, arising from the thorax of the host, $55 \sim 75 \times 1.5 \sim 2.5 \mathrm{~mm}$; head slightly wider than the stipe; perithecia semi-immersed, ellipsoid, ovoid or oval.

Host: Lepidopteran larvae, vertically buried in the soil.

Distribution: China (Zang et al. 1982) and Nepal (Shrestha \& Sung 2005, Adhikari 2008). M. liangshanensis described in Nepal differs from Chinese specimens in stromata length and other micromorphological characters (Zang et al. 1982, Shrestha \& Sung 2005, Adhikari 2008). Hence, further studies are required to verify the specimens collected in Nepal.

II) FAMILY Cordycipitaceae Kreisel ex Sung et al., Stud. Mycol. 57:48, 2007.

\section{2) Cordyceps coccinea Penz. and Sacc., Malpighia 11:524, 1897. (Fig. 2)}

Morphological characters: Stromata gregarious, filiform, dark red, $4 \sim 35 \times 0.3 \sim 0.5 \mathrm{~mm}$; head wider than stipe, lanceolate, fusiform, cylindrical or clavate in shape, granular on the surface due to prominent perithecial ostiole; perithecia immersed to superficial, compact, ovoid or conic.

Hosts: Coleopterous grubs, lepidopterous larvae and chrysalides pupae. The chitinous covering of the host is somewhat black. The host is subterraneous.

Distribution: Indonesia (Penzig \& Saccardo 1897), Sri Lanka (Petch 1924), Japan (Kobayasi 1941), Congo (Moureau 1949) and Nepal (Tanda \& Nagase 1994). Morphologically, this species is very similar to $C$. pruinosa (Teng 1936).

3) C. ishikariensis Kobayasi and Shimizu, Color Icon. Veg. Wasps Pl. Worms Pp. 176, 1994. (Fig. 3)
Morphological characters: Stromata gregarious, brown-yellow, arising from the thorax of the host, 45 65 1.5 2 mm; head continuous with the stipe and slightly broader than it; perithecia semi-immersed, ovoid to broadly ovoid.

Host: Cicada hymphs, vertically buried in soil.

Distribution: Japan (Shimizu 1994) and Nepal (Shrestha \& Sung 2005). This species was described only in Japanese and has not yet been accompanied by Latin description. Hence, Latin description is necessary to validate its taxonomic status.

4) C. militaris (L.: Fr.) Link, Hand. Gew. 3:347, 1833. (Fig. 4)

Morphological characters: Stromata solitary or gregarious, yellow to orange, $20 \sim 110 \times 1 \sim 6 \mathrm{~mm}$; head continuous with the stipe, but wider than it, cylindrical or slightly spherical; perithecia immersed to semiimmersed, ovoid or flask-shaped.

Hosts: Lepidopteran, coleopteran, hymenoptera and dipteran larvae and pupae, horizontally buried in soil.

Distribution: Worldwide distribution. It was described from Kathmandu Valley of Nepal by Shrestha \& Sung (2005). It is the type species of genus Cordyceps (Kobayasi 1941, Sung et al. 2007). This species has been successfully grown in artificial media.

5) C. martialis Speg., Bol. Acad. Nac. Ci. Córdoba 11:535, 1889. (Fig. 5)

Morphological characters: Stromata solitary or gregarious, sometimes branched, brownish orange, 35 65 $\times 1 \sim 3 \mathrm{~mm}$; head broader than the stipe, rough and dotted due to the ostioles of the perithecia; perithecia obliquely immersed, ovoid or flask-shaped with long neck.

Host: Coleopteran grubs, horizontally buried in soil.

Distribution: Brazil (Spegazzini 1889), Trinidad (Petch 1933), China (Teng 1934), North America (Mains 1958), Russia (Koval 1974), Japan (Kobayasi \& Shimizu 1982), Korea (Sung 1996) and Nepal (Shrestha \& Sung 2005). 
6) C. pruinosa Petch, Trans. Brit. Mycol. Soc. 10:38, 1924. (Fig. 6)

Morphological characters: Stromata gregarious, bright red, 15 40 $\times 0.5 \sim 1.5 \mathrm{~mm}$; head continuous with the stipe but broader than it, rough due to ostioles of perithecia; perithecia superficial

Host: Lepidopteran pupae, buried in soil.

Distribution: Sri Lanka (Petch 1924), China (Teng 1936), Japan (Kobayasi 1941), Congo (Moureau 1961), Russia
(Koval 1974), Korea (Sung 1996), Mexico (Guzman et al. 2001) and Nepal (Shrestha \& Sung 2005, Adhikari 2008). This species is very similar to C. coccinea (Teng 1936). It is locally known as Aalu Chhyau in Nepal.

III) FAMILY Ophiocordycipitaceae Sung et al., Stud. Mycol. 57:35, 2007.

7) Ophiocordyceps formicarum (Kobayasi) Sung et al., Stud. Mycol. 57:43, 2007. (Fig. 7)

E C. formicarum Kobayasi, Bull. Biogeogr. Soc. Japan 9:286, 1939.

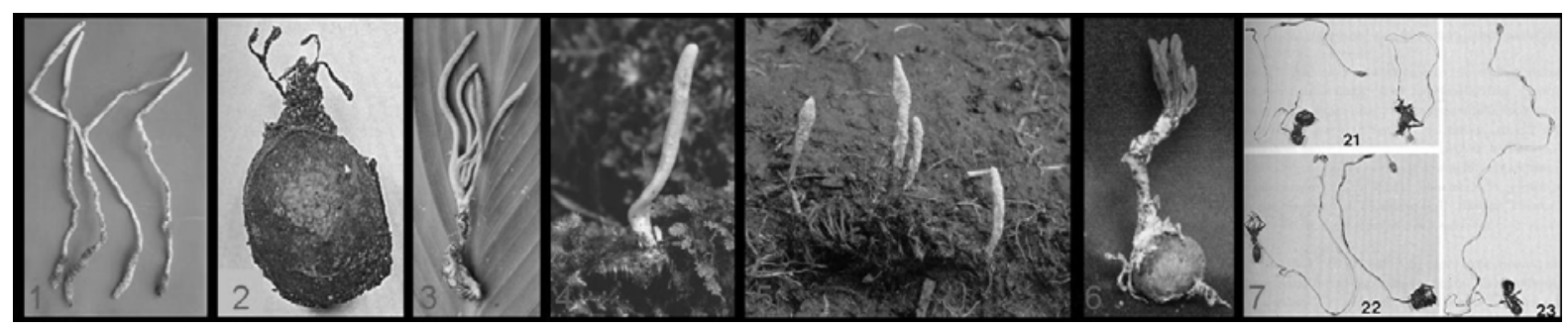

Fig. 1. Metacordyceps liangshanensis. Fig. 2. Cordyceps coccinea. Fig. 3. Cordyceps ishikariensis. Fig. 4. Cordyceps militaris. Fig. 5. Cordyceps martialis. Fig. 6. Cordyceps pruinosa. Fig. 7. Ophiocordyceps formicarum. (Sources: Figs. 1, 3, 4, 5 and 6 from Shrestha \& Sung 2005; Figs. 2 and 7 from Tanda \& Nagase 1994).

Morphological characters: Stromata solitary, filiform arising from abdomen and thorax of the host, 30 90 $\times$ $0.2 \sim 0.3 \mathrm{~mm}$; head distinct, ovate or fusiform, 1.4 2.1× 0.8 1.4 mm; perithecia obliquely immersed.

Host: Hymenopteran adults (ants), covered by decaying leaves or attached to them.

Distribution: Japan (Kobayasi 1939), Nepal (Tanda \& Nagase 1994), Korea (Sung 1996) and China (Li et al. 2002).

8) O. gracilis (Grev.) Sung et al., Stud. Mycol. 57:43, 2007. (Fig. 8)

三 Xylaria gracilis Grev., Scot. Crypt. Fl. 2. t. 86, 1824. E C.gracilis (Grev.) Durieu and Mont., Fl. Algérie Crypt. 1:449, 1846.

Morphological characters: Stromata solitary, occasionally two, stout, creamy white, smooth, arising from thorax, 30 60 $\times 1 \sim 3 \mathrm{~mm}$; head distinct, ovoid to subglobose, pinkish or brown-colored, punctate with ostioles of perithecia, $3 \sim 6 \times 3 \sim 4 \mathrm{~mm}$; perithecia completely immersed.
Host: Lepidopteran larvae, horizontally or vertically buried in soil.

Distribution: United Kingdom (Greville 1824), Algeria (Durieu 1846), France (Montagne 1856), North America (Ellis \& Everhart 1892), Brazil (Mçller 1901), Australia (Lloyd 1915), China (Teng 1934), Czech (Fassatiová 1954), Korea (Sung 1996), Nepal (Shrestha \& Sung 2005) and Slovakia (Kautman \& Kautmanová 2009).

\section{9) O. kangdingensis (M. Zang and N. Kinjo) Sung et al., Stud. Mycol. 57:44, 2007. \\ 三C. kangdingensis M. Zang and N. Kinjo, Mycotaxon 66:221, 1998.}

Morphological characters: Stromata solitary, simple, clavate, purplish brown to dark violet, arising from the thorax of the host, $62 \sim 75 \times 2 \sim 4 \mathrm{~mm}$; head abruptly enlarged from stipe with a sterile tip, rough or punctate with ostioles of perithecia; perithecia globoid or ovoid, almost immersed.

Host: larvae of Thitarodes spp., vertically buried in soil. 
Distribution: China (Zang \& Kinjo 1998) and Nepal (Adhikari 2008). These species resemble to O. sinensis, but differ in micromorphological characters (Zang \& Kinjo 1998).

10) O. multiaxialis (M. Zang and N. Kinjo) Sung et al., Stud. Mycol. 57:45, 2007.

E C. multiaxialis M. Zang and N. Kinjo, Mycotaxon 66:224, 1998.

Morphological characters: Stromata clavate, in cluster from two to four, purplish brown to dark brown, arising from thorox of host, $4 \sim 52 \times 1.5 \sim 3 \mathrm{~mm}$; head abruptly enlarged from the stipe with a sterile tip, long cylindrical, slender, punctate with ostioles of perithecia; perithecia globoid, slightly projecting.

Host: larvae of Thitarodes spp., vertically buried in soil.

Distribution: China (Zang \& Kinjo 1998) and Nepal (Adhikari 2008). It has some resemblance with $O$. kangdingensis in color and host, but differ from the latter in micromorphological characters (Zang \& Kinjo 1998).

11) O. nepalensis (M. Zang and Kinjo) Sung et al., Stud. Mycol. 57:45, 2007. (Fig. 9)

$\equiv$ C. nepalensis M. Zang and N. Kinjo, Mycotaxon 66:224, 1998.

Morphological characters: Stromata solitary, simple, clavate with a sterile tipe, purplish brown to dark brown, arising from the thorax of the host, $41 \sim 45 \times 2 \sim 5$ $\mathrm{mm}$; head gradually enlarged from stipe, almost smooth; perithecia globoid or ovoid, immersed.

Host: larvae of Heplialus nebulosus, vertically buried in soil.

Distribution: Endemic to Nepal (Zang \& Kinjo 1998, Adhikari 2008). It resembles with $O$. sinensis in color and is often misidentified, but differs from the latter in micromorphological characters (Zang \& Kinjo 1998).

12) O. nutans (Pat.) Sung et al., Stud. Mycol. 57:45, 2007. (Fig. 10)

E C. nutans Pat., Bull. Soc. Mycol. France 3:127, 1887.
Morphological characters: Stromata solitary to few, filiform, erect or somewhat curved, pallid, mainly arising from the thorax region of the host, black except orange yellow or reddish head, glabrous, 50 100 $\times$ 0.8 1.5 mm; head distinct, pod-like structure, fusiform or clavate, punctate with ostioles of perithecia; perithecia obliquely immersed with a long neck.

Host: Adults of hemipteran bugs, covered by decaying leaves and sometimes piercing through them.

Distribution: Japan (Patouillard 1887), New Guinea (Sydow 1922), China (Teng 1934), Congo (Moureau 1949), Korea (Lim \& Kim 1973), Russia (Koval 1974) and Nepal (Otani 1982, Shrestha 1985, Tanda \& Nagase 1994, Shrestha \& Sung 2005).

13) O. sinensis (Berk.) Sung et al., 57:46, 2007. (Fig. 11)

= Sphaeria sinensis Berk., J. Bot. (Hooker) 2:207, 1843.

三 C. sinensis (Berk.) Sacc., Michelia 1:320, 1878.

Morphological characters: Stromata solitary, rarely branched, dark brown to black, arising from the prothorax of the host, $40 \sim 100 \times 2 \sim 5 \mathrm{~mm}$; head continuous with the stipe with acuminate sterile tip, broader than stipe, punctuate to rough due to ostioles of perithecia; perithecia semi-immersed

Hosts: Larvae of Thitarodes (Hepialus) spp., Hepialiscus spp., Forkalus spp., Bipectilus spp., usually vertically buried in soil.

Distribution: Endemic to Tibetan Plateau and alpine grasslands of China, Nepal, Bhutan and India ranging from 3000 to $5000 \mathrm{~m}$ above sea level. Its historical records, geographical distributions, morphological variations and taxonomic complexities especially in light of discovery of similar species such as O. crassispora, O. gansuënsis, O. kangdingensis, O. multiaxialis and $O$. nepalensis have been recently reviewed (Shrestha et al. 2010). Many recent authors have opined that they are not distinct species; rather they are conspecific with $O$. sinensis and can be treated as its subspecies or forms or clades (Shrestha et al. 2010).

14) O. sphecocephala (Klotzsch ex Berk.) Sung et al. 57:47, 2007. (Fig. 12) 
E Sphaeria sphecocephala Klotzsch ex Berk., J. Bot. (Hooker) 2:206, 1843.

三C. sphecocephala (Klotzsch ex Berk.) Berk. and M.A. Curtis, J. Linn. Soc. Bot. 10:376, 1869.

Morphological characters: Stromata solitary or rarely two, filiform, arising from thorax to abdomen region of the host, erect or curved, pale-yellow to brownishyellow, glabrous, $14 \sim 70 \times 0.5 \sim 1 \mathrm{~mm}$; head distinct, abruptly enlarged from stipe, cylindric or fusiform or spherical; perithecium obliquely immersed with long neck.

Host: Adult wasps, covered by decaying leaves and sometimes attached to them.
Distribution: Cuba (Torrubia 1754), West Indies (Edwards 1764), Jamaica (Berkeley 1843), St. Vincents (Berkeley 1843), Guadeloupe (Tulasne \& Tulasne 1865), Argentina (Spegazzini 1881), Japan (Miyoshi 1888), Indonesia (Penzig \& Saccardo 1897), Brazil (Mçller 1901), North America (Seaver 1910), Guyana (Petch 1934), China (Teng 1934), Britain (Petch 1938), Czech (Šmarda 1941), Congo (Moureau 1949), India (Sen 1949), Korea (Lim \& Kim 1973), Russia (Koval 1974), Nepal (Tanda \& Nagase 1994, Shrestha \& Sung 2005) and Slovakia (Kautman \& Kautmanová 2009).

15) O. tricentri (Yasuda) Sung et al., 57:47, 2007. (Fig. 13)

三 C. tricentri Yasuda in Lloyd, Mycol. Writ. 4:568, 1916.

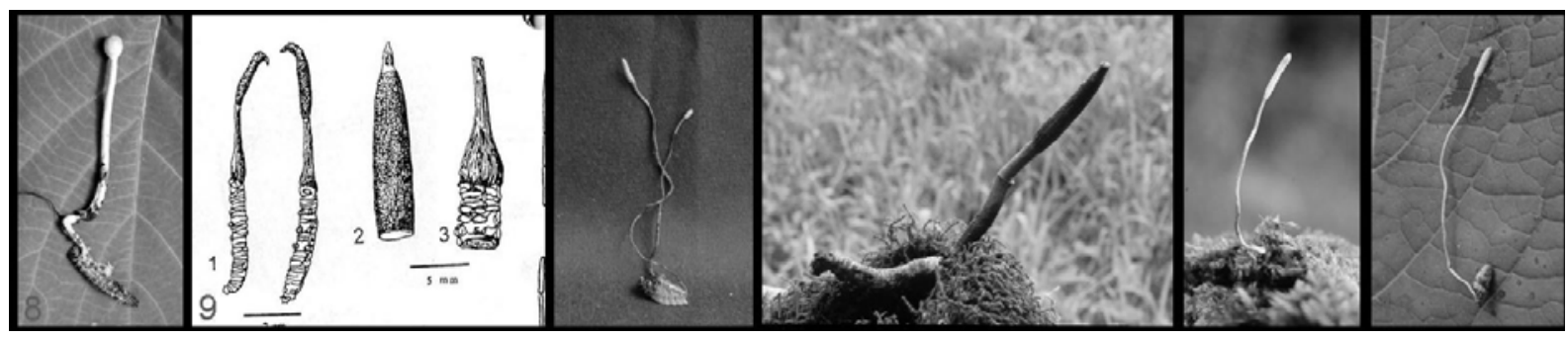

Figs. 8. Ophiocordyceps gracilis. Fig. 9. Ophiocordyceps nepalensis. Fig. 10. Ophiocordyceps nutans. Fig. 11. Ophiocordyceps sinensis. Fig. 12. Ophiocordyceps sphecocephala. Fig. 13. Ophiocordyceps tricentri. (Sources: Figs. 8, 10, 11, 12 and 13 from Shrestha \& Sung 2005; Fig. 9 from Zang \& Kinjo 1998).

Morphological characters: Stromata solitary, yellow, filiform, erect or curved, glabrous, arising from thorax region of the host, 35 50 $\times 0.25 \sim 0.3 \mathrm{~mm}$; head distinct, cylindric, fusiform or spherical; perithecia obliquely immersed.

Host: Adults of Aphrophora spp., covered by decaying leaves and sometimes attached to them, very easy to loose the host during collection due to its tiny size.

Distribution: Japan (Lloyd 1916), China (Teng 1934), Korea (Lim \& Kim 1973) and Nepal (Shrestha \& Sung 2005). It resembles pretty well with $O$. sphecocephala except the host.

Besides Cordyceps species, many other entomopathogenic fungi such as Beauveria spp., Hirsutella spp. and Isaria (Paecilomyces) spp. such as $I$. cicadae and $I$. japonica have been recorded in Nepal (Kobayasi 1965, Otani 1982, Mizuno 1999, Tanda \& Nagase 1994, Shrestha \& Sung 2005, Shrestha 2010a). The results described above show the richness of valuable entomopathogenic fungi in Nepal, mainly due to its diverse unique eco-geographical regions.
To date, 15 Cordyceps spp., recently classified as Cordyceps (5 spp.), Metacordyceps (1 sp.) and Ophiocordyceps (9 spp.), have been reported from Nepal. However, further collections are required to explore the hidden diversity of Cordyceps species. Nature conservation is of utmost importance to preserve Cordyceps species that depend upon living insects to complete their life cycle. Green Energy Mission/Nepal (GEM/Nepal), a non-profit research and development-oriented non-governmental organization, has been involved in scientific studies and public awareness of Cordyceps fungi and their medicinal values in Nepal.

\section{Acknowledgements}

The author wishes to express deep gratitude to Green Energy Mission/Nepal (GEM/Nepal), Kathmandu, Nepal for facilitating him during the research period and manuscript preparation. 


\section{References}

Adhikari, M.K. 2000. Mushrooms of Nepal. P.U. Printers, Kathmandu. 236 pp.

Adhikari, M.K. 2008. The diversity of Cordycepioid fungi (Ascomycotina: Clavicipitales) reported from Nepal. Bulletin of Department of Plant Resources 30:1-7.

Adhikari, M.K. and G. Durrieu. 1996. Ethnomycologie Nepalaise. Bulletin de la Société Mycologique de France 112:31-41.

Amatya, G. 2008. Trade and socio-economic attribution of Cordyceps sinensis (Berk.) Saccardo in Darchula district, Nepal. In: Medicinal plants in Nepal: An anthology of contemporary research (Eds. P.K. Jha, S.B. Karmacharya, M.K. Chettri, C.B. Thapa and B.B. Shrestha). Ecological Society (ECOS), Kathmandu. pp. 195-203.

Balfour-Browne, F.L. 1955. Some Himalayan fungi. Bulletin of the British Museum (Natural History) 1:189-218.

Berkeley, M.J. 1843. On some entomogenous Sphaeriae. Hooker's London Journal of Botany 2:205-211.

Berkeley, M.J. 1869. On a collection of fungi from Cuba: Part II. Journal of the Linnean Society 10:341-392.

Bhattarai, N.K. 1993. Folk herbal medicines of Dolakha district, Nepal. Fitoterapia 66:387-395.

Canney, S. 2006. Cordyceps sinensis - animal, vegetable or both? Journal of Chinese Medicine 80:43-49.

Chen, Y.J., Y.P. Zhang, Y.X. Yang and D. Yang. 1999. Genetic diversity and taxonomic implication of Cordyceps sinensis as revealed by RAPD markers. Biochemical Genetics 37:201-213.

Chen, Y.Q., B. Hu, F. Xu, W.M. Zhang, H. Zhou and L.H. Qu. 2004. Genetic variation of Cordyceps sinensis, a fruit-body-producing entomopathogenic species from different geographical regions in China. FEMS Microbiology Letters 230:153-158.

Chhetri, R. 2005. A study on Yarsagomba (Cordyceps sinensis (Berk.) Sacc.) in relation to livelihood and forest biodiversity in Darchula district of Nepal. M.Sc. Thesis, Kumaon University, Nainital, India.

Chhetri, R. and L.S. Lodhiyal. 2008. Collection of Cordyceps sinensis (Berk.) Sacc. (yarsagomba) and its implications to rural livelihood and biodiversity conservation: A case of Darchula, Nepal. In: Medicinal plants in Nepal: An anthology of contemporary research (Eds. P.K. Jha, S.B. Karmacharya, M.K. Chettri, C.B. Thapa and B.B. Shrestha). Ecological Society (ECOS), Kathmandu. pp. 214-223.

Devkota, S. 2006. Yarsagumba [Cordyceps sinensis (Berk.) Sacc.]; traditional utilization in Dolpa district, Western Nepal. Our Nature 4:48-52.

Devkota S. 2008a. Approach towards the harvesting of Cordyceps sinensis (Berk.) Sacc. in pastures of Dolpa, Nepal. In: Medicinal plants in Nepal: An anthology of contemporary research (Eds. P.K Jha, S.B. Karmacharya, M.K.Chetri, C.B.Thapa and B.B.
Shrestha). Ecological Sociey (ECOS), Kathmandu. pp. 90-96.

Devkota, S. 2008b. Distribution and status of highland mushrooms: a study from Dolpa, Nepal. Journal of Natural History Museum 23:51-59.

Devkota, S. 2009. The frequency and relationship of flowering plants on the distribution pattern of Ophiocordyceps sinensis (Yarchagunbu) in the highlands of Dolpa district, Nepal. Banko Janakari 19:29-36.

DMP. 1970. Medicinal plants of Nepal. Bulletin of the Department of Medicinal Plants (DMP) No. 9. Government of Nepal, Kathmandu, Nepal.

DPR. 1997. Fungi of Nepal Part II: Mastigomycotina, Zygomycotina and Ascomycotina. Bulletin of the Department of Plant Resources (DPR) No. 16. Government of Nepal, Kathmandu, Nepal.

Durieu, M. de. 1846. Flore d'Algérie, Cryptogamie. Paris. Vol. 1. 631 pp.

Edwards, G. 1764. Gleanings of natural history, containing figures of quadrupeds, birds, insects, plants, etc. London. Part 3. 347 pp.

Ellis, J.B. and B.M. Everhart. 1892. The North American Pyrenomycetes. Publ. by authors, New Jersey. 793 pp.

Fassatiová, O. 1954. Housenice menší, Cordyceps gracilis Grev., nova pro Èeskoslovensko. Ėeská Mykologie 8:2125.

Greville, R.K. 1824. Scottish cryptogamic flora. MacLachlan and Stewart, Edinburgh. Vol. 2. 121 pp.

Guzmán, G., M. Angel Morón, F. Ramírez-Guillén and J.H.D. Wolf. 2001. Entomogenous Cordyceps and related genera from Mexico with discussions on their hosts and new records. Mycotaxon 78:115-125.

Halpern, G.M. 1999. Cordyceps: China's healing mushroom. Avery Publishing Group, New York. 116 pp.

Halpern, G.M. 2007. Healing mushrooms. Square One Publishers, New York. 181 pp.

Holliday, J., M. Cleaver and S.P. Wasser. 2005. Cordyceps. In: Encyclopedia of dietary supplements. Dekker Encyclopedias. Taylor and Francis Publishing, London. pp. 1-13.

Jones, K. 1997. Cordyceps: Tonic food of ancient China. Sylvan Press, Washington. 50 pp.

Kautman, V. and I. Kautmanová. 2009. Cordyceps s.l. (Ascomycetes, Clavicipitaceae) in Slovakia. Catathelasma 11:5-48.

Kinjo, N. and M. Zang. 2001. Morphological and phylogenetic studies on Cordyceps sinensis distributed in Southwestern China. Mycoscience 42:567-574.

Kobayasi, Y. 1939. On the genus Cordyceps and its allies parasitic to Hymenoptera in Japan. Bulletin of the Biogeographical Society of Japan 9:271-290.

Kobayasi, Y. 1941. The Genus Cordyceps and its allies. Science Reports of the Tokyo Bunrika Daigaku (Section B, no. 84) 5:53-260. 
Kobayasi, Y. 1965. Himalayan Calostoma and Isaria. Journal of Japanese Botany 40:228-229.

Kobayasi, Y. 1980. Miscellaneous notes on the genus Cordyceps and its allies (14). Journal of Japanese Botany 55(6):20-29.

Kobayasi, Y. 1981. Revision of the genus Cordyceps and its allies 2. Bulletin of National Science Museum 7:123-129.

Kobayasi, Y. and D. Shimizu. 1982. Cordyceps species from Japan 5. Bulletin of National Science Museum 8:111-123.

Koval, E.Z. 1974. Opredelitel Entomofilnych Gribov CCCP. Kiev, USSR.

Li, C.R., M.Z. Fan, B. Huang, S.B. Wang and Z.Z. Li. 2002. The genus Cordyceps and its allies from Anhui I. Mycosystema 21:167-171.

Li, S.P. and K.W.K. Tsim. 2004. The biological and pharmacological properties of Cordyceps sinensis, a traditional Chinese medicine that has broad clinical applications. In: Herbal and traditional medicine: Molecular aspects of health (Eds. L. Packer, C.N. Ong and B. Halliwell). Marcel Dekker, New York. pp. 657684.

Li, S.P., F.Q. Yang and K.W.K. Tsimb. 2006. Quality control of Cordyceps sinensis, a valued traditional Chinese medicine. Journal of Pharmaceutical and Biomedical Analysis 41:1571-1584.

Lim, J.H. and B.K. Kim. 1973. Taxonomic investigations on Korean higher fungi (II): Two unrecorded species of the genus Cordyceps in Korea. Korean Journal of Mycology 1:13-16.

Link, J.H.F. 1833. Handbuch zur Erkennung der Nutzbarsten und am Haufigsten Vorkommenden Gewachse. Berlin. Part 3. 536 pp.

Liu, Z.Y., Y.J. Yao, Z.Q. Liang, A.Y. Liu, D.N. Pegler and M.W. Chase. 2001. Molecular evidence for the anamorph-teleomorph connection in Cordyceps sinensis. Mycological Research 105:827-832.

Lloyd, C.G. 1915. Synopsis of the Cordyceps of Australasia. Mycological Writings 4:1-12.

Lloyd, C.G. 1916. Mycological Notes. 41:558-572.

Mains, E.B. 1958. North American entomogenous species of Cordyceps. Mycologia 50:169-222.

Miyoshi, M. 1888. Review of vegetable wasps and plant worms. Botanical Magazine 2:36-40.

Mizuno, T. 1999. Medicinal effects and utilization of Cordyceps (Fr.) link (Ascomycetes) and Isaria Fr. (Mitosporic Fungi) Chinese caterpillar fungi, “Tochukaso" (Review). International Journal of Medicinal Mushrooms 1:251-261.

Möller, A. 1901. Phycomyceten und ascomyceten, untersuchungen aus Brasilien. In: Botanische Mittheilungen aus den Tropen Vol. 9 (Ed. A.F.W. Schimper). Verlag von Gustav Fischer, Jena. pp. 1319.
Montagne, C. 1856. Sylloge generum specierumque cryptogamarum. Paris. 498 pp.

Moureau, J. 1949. Cordyceps du Congo Belge. Memoirs Institute Royal Colonial Belge 7:1-58.

Moureau, J. 1961. Nouveaux Cordyceps du Congo. Lejeunia 15:5-38.

Otani, Y. 1982. Cordyceps fungi collected in Nepal Himalayas. Tôchûkasô 2:9-12.

Patouillard, N.T. 1887. Contributions a letude des champignons extra-europeens. Bulletin de la Société Mycologique de France 3:119-131.

Penzig, O. and P.A. Saccardo. 1897. Diagnoses fungorum novorum in insula Java collectorum. Malpighia 11:487530.

Petch, T. 1924. Studies in entomogenous fungi IV: Some Ceylon Cordyceps. Transactions of the British Mycological Society 10:28-45.

Petch, T. 1933. Notes on entomogenous fungi. Transactions of the British Mycological Society 18:48-75.

Petch, T. 1934. Contributions to the flora of tropical America XX: Entomogenous fungi from British Guiana. Kew Bulletin 5:202-205.

Petch, T. 1938. British Hypocreales. Transactions of the British Mycological Society 21:243-305.

Saccardo, P.A. 1878. Enumeratio pyrenomycetum hypocreaceorum hucusque congitorum systemate carpologico dispositorum. Michelia 1:277-325.

Sacherer, J. 1979. The high altitude ethnobotany of the Rolwaling Sherpas. Contributions to Nepalese Studies pp. CNAS, Tribhuvan University, Kathmandu. 6:45-64.

Seaver, F.J. 1910. Cordyceps (Hypocreales). North American Flora 3:1-56.

Sen, J. 1949. On the occurrence of Cordyceps sphecocephala (Kl.) Sacc. near Calcutta. Current Science 7:254-255.

Shimizu, D. 1994. Color iconography of vegetable wasps and plant worms. Seibundo Shinkosha, Tokyo. $368 \mathrm{pp}$.

Shrestha, B. 2010a. A study report on Cordyceps spp. of Kathmandu valley and its utilization. Green Energy Mission/Nepal, Kathmandu. 16 pp. (in Nepali).

Shrestha, B. 2010b. Cultivation of Yarsa gumba (Ophiocordyceps sinensis). Bigyan Lekhmala 358:411. (in Nepali)

Shrestha, B. 2010c. Yarsa gumba (Ophiocordyceps sinensis): A national pride of Nepal. SONSIK Souvenir 2(1):710 .

Shrestha, B. 2011. Yarsa gumba (Ophiocordyceps sinensis): Its importance, current situation and future policies. SONSIK Journal 3:6-11.

Shrestha, B. and J.M. Sung. 2005. Notes on Cordyceps species collected from the central region of Nepal. Mycobiology 33:235-239.

Shrestha, B., W.M. Zhang, Y.J. Zhang and X.Z. Liu. 2010. What is the Chinese caterpillar fungus Ophiocordyceps sinensis (Ophiocordycipitaceae)? Mycology 1:228-236. 
Shrestha, K. 1985. Cordyceps nutans Pat. from Lato Manang. Journal of Natural History Museum 9:111-114.

Singh, R., P. S. Negi and Z. Ahmed. 2010. Ophiocordyceps sinensis - valuable caterpillar fungus from the Himalayan hills. Current Science 99:865.

Šmarda, F. 1941. Cordyceps capitata Holmsk, housenice palièkovítá na Moravì. Pøíroda 34:106-108.

Spegazzini, C.L. 1881. Fungi Argentini. Anales de la Sociedad Cientifica Argentina 12:161-258.

Spegazzini, C.L. 1889. Fungi Puiggariani: Pugillus 1. Boletin de la Academia Nacional de Ciencias en Córdoba 11:381-625.

Sung, G.H., N.L. Hywel-Jones, J.M. Sung, J.J. Luangsaard, B. Shrestha and J.W. Spatafora. 2007. Phylogenetic classification of Cordyceps and the clavicipitaceous fungi. Studies in Mycology 57:5-59.

Sung, J.M. 1996. The Insects-Born Fungus of Korea in Color. Kyohak Publishing Co. Ltd., Seoul. 315 pp.

Sydow, H. 1922. Fungi novo-guineenses. In: Botanische Jahrbücher für Systematik, Pflanzengeschichte und Pflanzengeographie herausgegeben (Ed. A. Engler). Leipzig. 57:321-326.

Tanda, S. and M. Nagase. 1994. Cordyceps and its allied fungi from Nepal. Journal of Agricultural Science Tokyo Nogyo Daigaku 39:177-185.

Teng, S.C. 1934. Notes on Hypocreales from China. Sinensia 4:269-298.

Teng, S.C. 1936. Additional fungi from China III. Sinensia 7:529-530.
Torrubia, J. 1754. Aparato para la historia naturali Española. Madrid. Vol. 1. 204 pp.

Tulasne, L.R. and C. Tulasne. 1865. Selecta fungorum carpologia. Vol. 3. Paris Museum, Paris. 221 pp.

Weckerle, C.S., Y.P. Yang, F.K. Huber and Q.H. Li. 2010. People, money, and protected areas: The collection of the caterpillar mushroom Ophiocordyceps sinensis in the Baima Xueshan Nature Reserve, Southwest China. Biodiversity and Conservation 19:2685-2698.

Winkler, D. 2004. Yartsa Gunbu - Cordyceps sinensis: economy, ecology and ethno-mycology of a fungus endemic to the Tibetan Plateau. Memorie della Società Italiana di Scienze Naturali e del Museo Civico di Storia Naturale di Milano 33:69-85.

Winkler, D. 2008. Yartsa Gunbu (Cordyceps sinensis) and the fungal commodification of Tibet's rural economy. Economic Botany 62:291-305.

Winkler, D. 2010. Caterpillar fungus production and sustainability on the Tibetan Plateau and in the Himalayas. Chinese Journal of Grassland 32(Suppl.):96-108.

Zang, M. and N. Kinjo. 1998. Notes on the alpine Cordyceps of China and nearby nations. Mycotaxon 66:215-229.

Zang, M., D.Q. Liu and R.Y. Hu. 1982. Notes concerning the subdivisions of Cordyceps and a new species from China. Acta Botanica Yunnanica 4:173-176.

Zhu, J.S., G.M. Halpern and K. Jones. 1998. The scientific rediscovery of an ancient Chinese herbal medicine: Cordyceps sinensis Part I. Journal of Alternative and Complementary Medicine 4:289-303. 